УДК 340.1(045)

DOI https://doi.org/10.51989/NUL.2021.6.11

\title{
КОЛІЗІЇ У ПРАВІ: ТЕОРЕТИКО-МЕТОДОЛОГІЧНІ ПІДХОДИ ДО ВИЗНАЧЕННЯ ТА КЛАСИФІКАЦІЇ
}

\author{
Звонарьов Валентин Вадимович, \\ аспірант Маріупольського державного університету, \\ адвокат Адвокатського бюро «Мироненко та партнери»
}

Досліджено теоретичні підходи до визначення колізій у праві. Проаналізовано поняття колізійної норми як способу вирішення правових колізій і конфліктів. Показано нормативно-правову невизначеність поняття «колізія» у національному українському законодавстві. Наголошено на відсутності комплексного підходу у профільних дослідженнях до проблематики адміністративно-правових конфліктів із відповідним аналізом практики їх подолання, включаючи колізійні питання застосування законодавства про адміністративну відповідальність і колізійні проблеми адміністративного судочинства. Відзначено реалізацію в Україні протягом останніх років адміністративної реформи, процес якої неодмінно породжує адміністративно-правові колізії, прогалини та конфліктні питання адміністративно-правового статусу органів публічної влади, баланс функцій і повноважень яких має забезпечувати нормальне функціонування держави. Визначено, що у чинному українському законодавстві немає нормативного визначення понять «колізія» та «колідуюча норма», натомість в окремих нормативно-правових актах, які належать до сфери дії міжнародного приватного права, визначається поняття колізійної норми як способу вирішення юридичної колізії з іноземним елементом. Показано, що прогалини у нормативно-правовому регулюванні юридичних колізій потребують розроблення комплексного, широкого теоретико-методологічного підходу, який охоплює як формально-юридичні колізії, так і фактологічні правові конфлікти (наприклад, у вигляді суперечностей між змістом норми права та реальним станом суспільних відносин; між позитивним і природним правом; між публічним порядком і приватним інтересом тощо). Доведено, що розв'язання правових колізій і конфліктів слід вважати важливим елементом визначеної у чинному законодавстві компетенції органів публічної влади на рівні правотворчості, правотлумачення та правозастосування.

Ключові слова: колізія, колізійна норма, правовий конфлікт, нормативно-правове регулювання, публічна влада.

\section{Zvonarov Valentyn. The conflicts in law: theoretical and methodological approaches to definition and classification}

Theoretical approaches to the definition of conflicts in law are studied. The concept of conflict rule as a way to resolve legal conflicts and conflicts is analyzed. The normative and legal uncertainty of the concept of "conflict" in the national Ukrainian legislation is shown. It is emphasized that there is no comprehensive approach in specialized research to the issue of administrative and legal conflicts with appropriate analysis of the practice of overcoming them, including conflicting issues of application of legislation on administrative liability and conflicting issues of administrative proceedings. The implementation of administrative reform in Ukraine in recent years is noted, the process of which inevitably creates administrative and legal conflicts, gaps and conflicts in the administrative and legal status of public authorities, the balance of functions and powers of which should ensure the proper functioning of the state. It is determined that in the current Ukrainian legislation there is no normative definition of the concepts of "conflict" and "conflict rule", while in some regulations relating to the scope of private international law, defines the concept of conflict rule as a way to resolve legal conflicts with foreign elements. It is shown that gaps in the legal regulation of legal conflicts require the development of a comprehensive, broad theoretical and methodological approach, covering both formal legal conflicts and factual legal conflicts (for example, in the form of contradictions between the content of law and the real state of public relations; between positive and natural law, between public order and private interest, etc.). It has been proved that the resolution of legal conflicts and conflicts should be considered an important element of the competence of public authorities at the level of lawmaking, interpretation and law enforcement defined in the current legislation.

Key words: conflict, conflict rule, legal conflict, normative-legal regulation, public authority. 
Дослідження адміністративно-правових колізій і конфліктів із погляду проблем теорії та практики актуальне на сучасному етапі розвитку української національної правової системи, оскільки безпосередньо відображає стан адміністративно-правових відносин у суспільстві й охоплює декілька важливих аспектів, серед яких необхідно насамперед відзначити: а) реалізацію в Україні протягом останніх років адміністративної реформи, процес якої неодмінно породжує адміністративно-правові колізії, прогалини та конфліктні питання адміністративно-правового статусу органів публічної влади, баланс функцій і повноважень яких має забезпечувати нормальне функціонування держави; б) виникнення із 1991 р. і дотепер декількох гострих парламентсько-урядових і загальносуспільних криз, викликаних наявністю колізій і прогалин у правовому регулюванні адміністративно-правових відносин на вищому рівні державної влади в Українській державі; в) відсутність комплексного підходу у профільних дослідженнях до проблематики адміністративно-правових конфліктів із відповідним аналізом практики їх подолання, включаючи колізійні питання застосування законодавства про адміністративну відповідальність і колізійні проблеми адміністративного судочинства.

Все це зумовлює важливість дослідження шляхів подолання адміністративно-правових колізій і конфліктів. Урахування у майбутньому відповідних рекомендацій дозволить уникнути протистоянь у суспільстві, передусім між різними рівнями публічного адміністрування, включаючи колізії та конфліктні ситуації щодо розмежування компетенції публічно-владних суб'єктів.

Безпосередньою метою статті $\epsilon$ розкриття теоретико-методологічних підходів до визначення та класифікації колізій у праві, без чого вбачається неможливим подальший якісний аналіз галузевих колізій, прогалин і правових конфліктів.

Варто зазначити, що окремі питання проблематики визначення колізій у праві були досліджені різними науковцями представниками як загальної теорії держави та права, так і галузевих юридичних наук.

Зокрема, слід відзначити праці таких вітчизняних учених, як В.Б. Авер'янов,
К.А. Бабенко, Ю.П. Битяк, П.А. Бурковський, Є.В. Годованик, О.В. Зайчук, В.В. Колпаков, О.С. Передерій, В.Ф. Погорілко, М.В. Савчин, Ю.М. Тодика, В.Л. Федоренко, В.М. Шаповал. У зарубіжній літературі визначне місце посідають роботи Г. Істера, Г. Каспера, К. Фрайдріча, С. Франкса, Ю.О. Тихомирова, 3. Ютсі та ін.

Як вбачається, дослідження колізій у праві потребує визначення належних, коректних і доцільних методологічних підходів, а також чіткого встановлення понять і категорій, необхідних для розкриття практичних механізмів подолання колізійних ситуацій нормативно-правого регулювання.

За загальним науковим визначенням Словника іншомовних слів, колізія (лат. collisio) - це «1) зіштовхнення протилежних інтересів, прагнень, інтересів; 2) [юридичне] розходження між окремими законами однієї держави або суперечність законів, судових рішень різних держав» [1, с. 241].

Водночас Ю.О. Тихомиров у контексті розгляду питання про юридичні колізії та їхню іманентну природу вважає «суперечності, що виникають у всіх сферах життя громадянина, держави та суспільства загалом», нашими «вічними супутниками», причому конфлікти, спори, зіткнення людей, на його думку, існували у всі часи [2, с. 3]. На погляд вченого, «колізія - це сьогоднішній спільний знаменник намірів, дій, вчинків» [3, с. 19].

Безпосередньо сам термін «колізія» етимологічно походить від латинського «collide» - «стикаюся» - й означає сутичку, збіг протилежних обставин, сил та інтересів [4]. Класичним виразом колізії $\epsilon$ суперечність між «наявним» і «необхідним», а якщо взяти до уваги ту обставину, що закон закріплює «наявне», а у праві міститься «належне» чи «необхідне», то юридичні колізії у найбільш глобальному масштабі полягають у суперечностях між позитивним законом і природним правом.

Будь-яку колізію можна оцінити з юридичного погляду, особливо тоді, коли ставиться за мету її подолання. На думку того ж Ю.О. Тихомирова, і «право, і правові акти завжди були «учасниками» сварок і примирень, спорів і домовленостей, 
конфліктів та угод, війн і миру. Вони <...> як привід і мета, як арбітр і суддя, як засіб узгодженості інтересів» [3, с. 3].

Варто зазначити, що легалізованого (тобто нормативного, законодавчого) поняття «колізія», його дефініції чинне законодавство України не містить. У систематизованому вигляді відсутнє воно й у загальній теорії права, а тим більше в адміністративному праві, з урахуванням специфічних особливостей його галузевого предмету та методу [5, с. 320].

У деяких законодавчих актах України сьогодні лише згадується про нормативні колізії без визначення змісту цього поняття. Так, у Законі України «Про міжнародний комерційний арбітраж» [6] у ст. 28 «Норми, що застосовуються до суті спору» закріплене положення про те, у яких випадках третейський суд у вирішенні спору застосовує колізійні норми, а Кодекс торговельного мореплавства [7] у ст. 14 містить перелік колізійних норм, які застосовуються у відносинах морського перевезення вантажів, фрахтування судна, лізингу тощо. П. 3 ч. 1 ст. 1 Закону України «Про міжнародне приватне право» розкриває поняття колізійної норми, розуміючи під нею «норму, що визначає право якої держави підлягає застосуванню до правовідносин 3 іноземним елементом» [8], але водночас визначення поняття «колізія» у вказаному нормативно-правовому акті відсутнє, залишаючи вирішення цього досить важливого теоретико-методологічного і практичного питання виключно теорії міжнародного приватного права на рівні доктринального неофіційного тлумачення.

Загалом, з огляду на подібну притаманну правовим системам багатьох держав недостатню регламентацію юридичних колізій і способів їх подолання, Ю.О. Тихомиров у дослідженнях юридичних колізій змушений констатувати, що «проблема колізій у глобальному масштабі не ставиться і не вирішується, вона зводиться до колізійного права і колізійних норм, котрі приписують, які акти застосовувати, коли виникає суперечлива ситуація» [3, с. 8]. Як можна побачити, подібний вузький і методологічно обмежений підхід якраз і застосовується у текстуальній побудові Закону України «Про міжнародне приватне право», у якому роз- кривається спосіб вирішення юридичних колізій, викликаних наявністю іноземного елемента - прийняття та взаємне визнання колізійних норм, але не сама проблема наявність законодавчих колізій чи, іншими словами, колідуючих норм.

Як вбачається, слід достатньо чітко відрізняти колідуючи норми, тобто такі, що вступають у колізію між собою, від колізійних норм, спрямованих на усунення чи вирішення юридичної колізії, породженої наявністю колідуючих норм або колідуючих правопорядків (міжнародних, міжобласних або темпоральних).

Більше того, у радянські часи вважалося, що навіть для прийняття та застосування колізійних норм немає об'єктивних передумов, адже у разі виникнення колізій (а основною їх причиною вважалися недоліки кодифікації) вони повинні були розв'язуватися залежно від юридичної сили та субпідрядності норм або на підставі правил дії правових норм у часі [9, с. 28]. Дослідження вчених-юристів із цієї проблеми стримувало, мабуть, політичне «табу» на аналіз суспільних суперечностей і конфліктів, що стало причиною відсутності системного підходу для їх обґрунтування та подолання. Крім того, у панівній тоді філософії марксизму-ленінізму в її радянській інтерпретації пропонувалося відрізняти суперечності від антагонізму, причому суперечності вважалися необхідними для суспільного прогресу, а процес їх подолання - шляхом до розбудови комунізму [10, с. 284].

Отже, у зв'язку з названими причинами усі наявні поняття юридичних колізій (колізій у праві, конфліктів у праві) нині можна знайти лише в енциклопедичних, словникових виданнях, а також деяких поодиноких монографічних дослідженнях, але ті терміни, що у них містяться, такі як «колізія», «колізія законів», «колізія прав», «колізійне право», «колізійна норма», «колізійна прив'язка» $€$ недостатніми для теоретичного і наукового обґрунтування проблеми (зокрема у наведеному переліку слід звернути увагу на фактичну відсутність у наукових працях поняття «колідуючі норми», хоча їх існування саме і становить колізію у праві, а колізійні норми є вторинними, такими, що прийняті для усунення колізійної ситуації між 
колідуючими нормами). Подібні міркування висловлює і Ю.М. Тодика, на погляд якого «безконфліктна модель розвитку суспільних відносин, котра панувала у 80-х рр. на пострадянському просторі, не спонукала до наукових пошуків причин появи та шляхів вирішення конфліктів у політико-правовій сфері. Визнавалося, що за соціалізму існують тільки неантагоністичні суперечності, а тому керівництво багатьох країн СНД виявилося безсилим перед розв'язанням конфліктів, насамперед у державно-правовій сфері» [11, с. 58].

Словникові визначення колізій у зв'язку із цим не можна вважати повною мірою науковими, тим більше спеціальними юридичними, а їх енциклопедична лаконічність зручна і корисна на загальному пізнавальному рівні, але не завжди дозволяє розробити належний інструментарій для оптимального вирішення практичних колізійних ситуацій в окремих галузях права.

Аналіз наукових публікацій і ґрунтовних праць із проблеми правових колізій також показує неоднозначний підхід вчених-правознавців до цього складного суспільного явища.

Досліджуючи наукову проблему колізій у праві, фахівці використовують синоніми цього слова: «суперечності», «конфлікти», «конкуренція», «спір», «зіткнення», «протилежність», «розбіжність», «розходження», «антагонізм», «неузгодженість», «взаємовиключення» та ін., чим створюють колізійні ситуації уже на доктринальнонауковому рівні, оскільки, за слушним твердженням М.I. Панова, «у науці використовуються різні поняття стосовно проблеми колізій у праві. Йдеться про колізії, суперечності, конкуренцію норм, конкуренцію законів. У деяких випадках ці поняття протиставляють і колізіям, і конкуренції законів загалом властива найбільш характерна ознака. Це внутрішня суперечність» [9, с. 28]. Натомість протилежної думки дотримується Д. Письменний, котрий переконаний, що змішувати колізію з конкуренцією норм неприпустимо, бо «це зовсім різні поняття. У колізії містяться норми, які суперечать одна одній, для колізій характерна наявність декілька норм, що відрізняються за змістом одна від одної. За конкуренції норм ніякої колізії не може бути, можливі два види кон- куренції: загальної та спеціальної норми, а також спеціальних норм. Зазначимо, що конкуренція - це більш складне явище, ніж колізія. У ній переплітаються питання факту з питанням права...» $[12$, с. 80$]$.

Узагальнюючи суперечності у межах правової системи Німеччини як «конфлікти», 3. Ютсі говорить про два їх види: конкуренцію основних прав і їх колізію. Принципова різниця між ними, на його думку, полягає у тому, що «конкуренція основних прав виникає тоді, коли стосовно поведінки носія основних прав може застосовуватися декілька прав. На відміну від питання конкуренції основних прав, тут ідеться не про рівне ієрархічне розташування основних прав до особи громадянина, а про протилежності одного або декількох прав до кількох носіїв основних прав» $[13$, с. 31]. Отже, 3. Ютсі розглядає конкуренцію швидше як альтернативу для одного суб'єкта вибрати 3-поміж різних, але не суперечливих за предметом свого правового регулювання, правових норм ту, яка більш за все захистить його порушене чи таке, що заперечується, право або законний інтерес. Вбачається, що конкурентні правові норми ніколи не можуть вступити у суперечність, оскільки вони несуть однакове правове навантаження для суб'єкта, $\epsilon$ однакові за змістом, а застосування будь-якої з них дає ідентичний результат.

Отже, з усіх названих синонімів поняття «колізія» лише «конкуренція» не $\epsilon$ суперечністю, бо вона $\epsilon$ змагальністю за пріоритетність. Викладене свідчить про те, що словникове визначення юридичної колізії не охоплює всіх її аспектів. Суттєвим елементом це поняття доповнює 3. Ютсі, на чий погляд, «такі колізії виникають тоді, коли дві норми застосовуються щодо одного і того самого факту, і їх застосування призводить до різних результатів» [13, с. 30]. Таким чином, вважається, що у разі застосування колізійних правових норм обов'язково настають різні результати. Із цим важко не погодитися, адже настання однакового результату в такій ситуації було 6 очевидним фактом відсутності колізії. Настання однакового результату у разі застосування різних правових норм щодо одного й того самого предмета регулювання може лише підтверджувати висловлену вище думку про те, що ці норми $€$ не колізійними, 
а альтернативними. Вони лише конкурують між собою в очах суб'єкта їх застосування, який має право вибору однієї з них або всіх разом. Істотну поправку для визначення поняття юридичної колізії дає Д. Письменний, на думку котрого, «у колізії містяться норми, які суперечать одна одній і відрізняються за змістом» [12, с. 80]. Отже, для колізійності правових норм вони мають відрізнятися не лише за результатом їх застосування, а й за своїм змістом. Слід також зробити акцент на тому, що, мабуть, автор мав на увазі не лексичний зміст правових норм, а правовий (формально-юридичний) зміст.

Підсумовуючи наведені теоретико-методологічні підходи, можна цілком погодитися з думкою Д. Лилака, що колізія - це стан і дія кількох правових актів чи їх норм, зазвичай нормативного характеру, прийняті одним або різними суб'єктами правотворчості, які спрямовані на регулювання одних і тих самих суспільних відносин, а застосування кожного з них окремо дає різний, зокрема протилежний, результат. Колізійні правові акти та норми є контраверсійними, оскільки розбігаються за результатами (не тільки фактичними, але й очікуваними) їх регулятивної дії на суспільні відносини [4].
Загалом у результаті проведеного дослідження теоретико-методологічних підходів до визначення та класифікації колізій у праві можна дійти таких найважливіших висновків: а) у чинному українському законодавстві відсутнє нормативне визначення понять «колізія» та «колідуюча норма», натомість в окремих нормативно-правових актах, що належать до сфери дії міжнародного приватного права, визначається поняття колізійної норми як способу вирішення юридичної колізії з іноземним елементом; б) прогалини у нормативноправовому регулюванні юридичних колізій потребують розроблення комплексного, широкого теоретико-методологічного підходу, що охоплює як формально-юридичні колізії, так і фактологічні правові конфлікти (наприклад, у вигляді суперечностей між змістом норми права та реальним станом суспільних відносин; між позитивним і природним правом; між публічним порядком і приватним інтересом тощо); в) розв'язання правових колізій і конфліктів слід вважати важливим елементом визначеної у чинному законодавстві компетенції органів публічної влади на рівні правотворчості, правотлумачення та правозастосування.

\section{ЛITEPATУPA:}

1. Словарь иностранных слов. Москва : Русский язык, 1989. 624 с.

2. Тихомиров Ю.А. Юридическая коллизия. Москва, 1994. 140 с.

3. Тихомиров Ю. А. Колизионное право : учебное и научно-практическое пособие. Москва, 2000. 394 с.

4. Лилак Д. Колізія і конкуренція законів. Право України. 2001. № 4. URL: https:// pravoznavec.com.ua/period/chapter/2/19/567 (дата звернення: 03.12.2021р.).

5. Загальна теорія держави і права / за ред. В.В. Копєйчикова. Київ, 1988. 320 с.

6. Про міжнародний комерційний арбітраж : Закон України від 24 лютого 1994 р. Відомості Верховної Ради України. 1994. № 25. Ст. 198.

7. Кодекс торгівельного мореплавства : Закон України від 23 травня 1995 р. Відомості Верховної Ради України. 1995. № 47. Ст. 349.

8. Про міжнародне приватне право : Закон України від 23 червня 2005 р. Відомості Верховної Ради України. 2005. № 32. Ст. 422.

9. Панов Н.И. Некоторые вопросы коллизий в законодательстве Украины. Колізії у законодавстві України: проблеми теорії і практики. Матеріали Міжнародної науково-практичної конференції (м. Київ, 23-24 жовтня 1995 р.). Київ, 1996. С. 25-28.

10. Куусинен О. Основы марксизма-ленинизма. Москва, 1960. 774 с.

11. Тодика Ю.М. Функціонування державної влади в аспекті конфліктології. Правова держава. 1997. Вип. 8. С. 52-60.

12. Письменний Д.П. Колізії в кримінально-процесуальному законодавстві України: способи їх подолання. Матеріали Міжнародної науково-практичної конференції (м. Київ, 23-24 жовтня 1995 р.). Київ, 1996. С. 78-82.

13. Ютси 3. Проблемы коллизий в законодательстве Федеративной Республики Германия. Матеріали Міжнародної науково-практичної конференції (м. Київ, 23-24 жовтня 1995 р.). Київ, 1996. С. 29-32. 